\title{
Synthesis and crystal structure of $\mathrm{Fe}_{6} \mathrm{Ca}_{2}\left(\mathrm{SeO}_{3}\right)_{9} \mathrm{Cl}_{4}-$ a porous oxohalidet
}

Cite this: Dalton Trans., 2013, 42, 7859

Received 28th February 2013,

Accepted 11th April 2013

DOI: $10.1039 / c 3 d t 50952 d$

www.rsc.org/dalton

\author{
Shichao Hu and Mats Johnsson
}

A porous oxohalide, $\mathrm{Fe}_{6} \mathrm{Ca}_{2}\left(\mathrm{SeO}_{3}\right)_{9} \mathrm{Cl}_{4}$, has been synthesized by solid state reactions using concentrated $\mathrm{HCl}$ as the $\mathrm{Cl}$-source. It crystallizes in the hexagonal space group $P 6_{3} / m$ with unit cell parameters $a=12.118(2) \AA, c=12.703(4) \AA, Z=2$. The crystal structure is an open framework having one-dimensional channels extending along [001] that the chlorine atoms and lone pairs on $\mathrm{Se}^{4+}$ are facing. The channels in this framework structure are unusually large compared to other oxohalide compounds and also accessible to guest molecules. Water vapor sorption measurements show an uptake of $9 \mathrm{wt} \%$ at $293 \mathrm{~K}$.

Oxohalide compounds containing p-block elements in low oxidation states carrying a stereochemically active lone-pair are a group of compounds rich in unusual crystal structures. Examples of such lone-pair elements are $\mathrm{Se}^{4+}, \mathrm{Te}^{4+}, \mathrm{Sb}^{3+}, \mathrm{Bi}^{3+}$, etc., that all adopt an asymmetric or one-sided coordination. The non-bonding lone-pair electrons occupy a volume similar to that of oxygen resulting in open non-bonding volumes in the crystal structure. ${ }^{1-3}$

When introducing a late transition metal cation into the system the lone-pair cations most often form bonds only to oxygen due to their high Lewis acid strength and small radius while the transition metal cations bond to both oxygen and halide ions. The combination of stereochemically active lonepair cations and halide ions that often are terminating in the crystal structure act both as "chemical scissors" to open up the structures and to increase the possibilities for low-dimensional arrangements of transition metals. ${ }^{4,5}$ A number of compounds with unusual crystal structures have been synthesized by utilizing this synthesis concept. This kind of compound may show interesting physical properties such as magnetic frustration because of the increased possibility for metals to adopt low-dimensional

Department of Materials and Environmental Chemistry, Stockholm University, SE-10691 Stockholm, Sweden. E-mail: mats.johnsson@mmk.su.se;

Fax: +46-8-15 21 87; Tel: +46-8-1621 69

†Electronic supplementary information (ESI) available: Experimental details, crystal structure refinement parameters, bond valence sum (BVS) calculations, EDS-analysis data, sorption isotherms, PXRD-data. See DOI: 10.1039/c3dt50952d arrangements in the crystal structure ${ }^{6,7}$ or nonlinear optical second harmonic generation ( $\mathrm{SHG}$ ) because of the increased possibility to form noncentrosymmetric crystal structures due to the one-sided coordination of the lone-pair cations. ${ }^{8-10}$

There are two main structure types for this family of oxohalide compounds: (i) layered compounds with strong covalent/ ionic bonds within the layers and weaker van der Waal interactions between the layers, e.g. $\mathrm{Cu}_{3}\left(\mathrm{TeO}_{3}\right)_{2} \mathrm{Br}_{2}, \mathrm{Co}_{2} \mathrm{TeO}_{3} \mathrm{Cl}_{2}$ and $\mathrm{FeTe}_{3} \mathrm{O}_{7} \mathrm{X}(\mathrm{X}=\mathrm{Cl}, \mathrm{Br}),{ }^{4,11,12}$ and (ii) open framework structures having channels where the lone-pairs and halide ions are located, e.g. $\quad \mathrm{Fe}_{3} \mathrm{Te}_{3} \mathrm{O}_{10} \mathrm{Cl}, \quad \mathrm{Ni}_{5}\left(\mathrm{SeO}_{3}\right)_{4} \mathrm{Br}_{2}$ and $\mathrm{Ni}_{15} \mathrm{Te}_{12} \mathrm{O}_{34} \mathrm{Cl}_{10} \cdot{ }^{13-15}$ The sizes of such channels are 3-4 $\mathrm{A}$ in diameter at maximum and thus similar to the pore size in many zeolites; however they are not accessible for e.g. gasuptake because a substantial part of the pore volume is occupied by the lone-pair electrons and terminating halide ions. It is therefore interesting to further increase the pore size in oxohalide compounds to explore if the voids can be utilized for catalytic reactions or gas uptake. In the present study an alkaline earth metal was included in addition to a transition metal and a new compound $\mathrm{Fe}_{6} \mathrm{Ca}_{2}\left(\mathrm{SeO}_{3}\right)_{9} \mathrm{Cl}_{4}$ was found that exhibits channels with a diameter of $\sim 6.4 \AA$ A. To the best of our knowledge this is the largest pore diameter described for such an oxohalide compound, see Fig. 1.

The compound $\mathrm{Fe}_{6} \mathrm{Ca}_{2}\left(\mathrm{SeO}_{3}\right)_{9} \mathrm{Cl}_{4}$ 1 $\neq$ was synthesized from solid state reactions. ${ }^{16}$ The crystal structure was solved from single crystal X-ray diffraction and it crystallizes in the hexagonal space group $P 6_{3} / m$ with unit cell parameters $a=12.118(2)$ $\AA$ and $c=12.703(4) \AA$. EDS-analysis confirms the chemical composition and bond valence sum (BVS) calculations support that the oxidation states of the cations are $\mathrm{Ca}^{2+}, \mathrm{Fe}^{3+}$ and $\mathrm{Se}^{4+}$, respectively, see ESI. $\uparrow$ Small single crystals of the isostructural Br-analogue $\mathrm{Fe}_{6} \mathrm{Ca}_{2}\left(\mathrm{SeO}_{3}\right)_{9} \mathrm{Br}_{4} 2$ were also synthesized following the same procedure except that $\mathrm{HBr}$ was used as the transporting agent instead of $\mathrm{HCl}$. Compound 2 has unit cell parameters $a=$

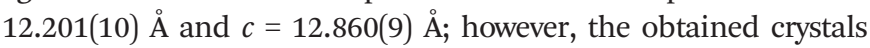
were too small to collect single crystal data good enough for an accurate crystal structure refinement. Attempts were made to synthesise also the Te-analogue but those attempts failed. 


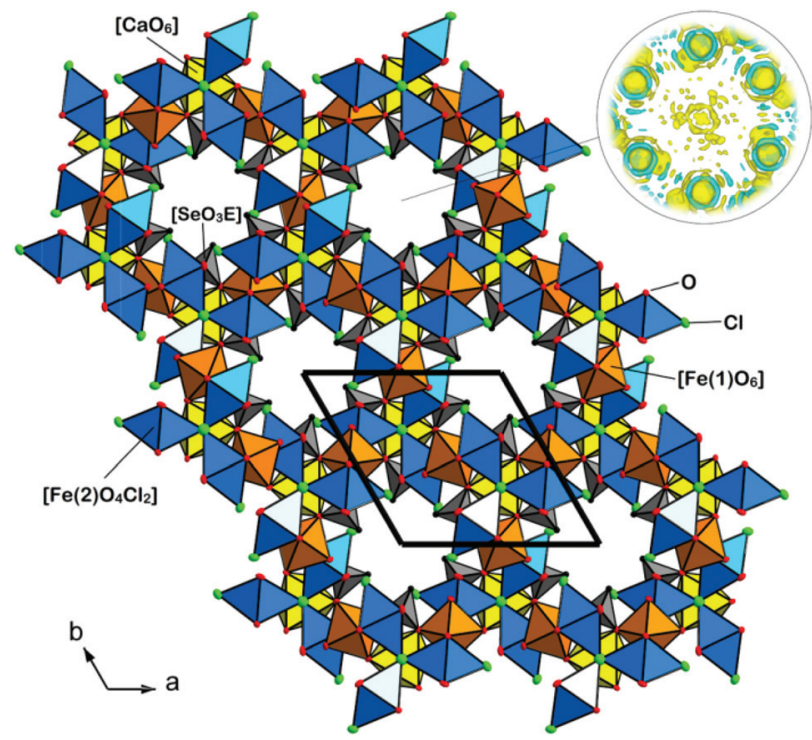

Fig. 1 Overview of the crystal structure of $\mathrm{Fe}_{6} \mathrm{Ca}_{2}\left(\mathrm{SeO}_{3}\right)_{9} \mathrm{Cl}_{4}$ along [001]. Channels $\sim 6.4 \AA$ in diameter extend along [001] that $\mathrm{Cl}^{-}$and the lone-pair on $\mathrm{Se}^{4+}$ are facing. The inset shows a channel and the electron density in the center represents adsorbed water molecules.

The crystal structure of $\mathbf{1}$ can be described as a threedimensional open framework with channels extending along [001], see Fig. 1.

The symmetry of this structure means that $\mathrm{Se}(1)$ is at a site with $m$ symmetry, $\mathrm{Fe}(2)$ is on an inversion centre, $\mathrm{Fe}(1)$ is on a mirror plane, $\mathrm{Ca}(1)$ is on a threefold axis, $\mathrm{Cl}(2)$ is at a site with -6 symmetry, and $\mathrm{Cl}(1)$ is at a site with $m$ symmetry. There are two crystallographically different $\mathrm{Se}^{4+}$ ions that both have the common tetrahedral $\left[\mathrm{SeO}_{3} \mathrm{E}\right]$ coordination, where $\mathrm{E}$ represents the stereochemically active lone-pairs occupying a nonbonding orbital. The Se-O bond distances range from 1.658(9) $\AA$ to $1.751(5) \AA$. The $\left[\mathrm{SeO}_{3} \mathrm{E}\right]$ polyhedra are isolated from each other, which is in analogy with observations that such polyhedra seldom polymerize. ${ }^{17}$ The crystallographically unique Ca-atoms bond to six oxygen atoms to form $\left[\mathrm{CaO}_{6}\right]$ octahedra with $\mathrm{Ca}-\mathrm{O}$ bond distances in the range 2.361(4) $\AA$ to 2.378(5) A. Two such octahedra connect to each other by sharing $(\mathrm{O} 2-\mathrm{O} 2-\mathrm{O} 2)$ faces to form $\left[\mathrm{Ca}_{2} \mathrm{O}_{9}\right]$ dimers with $\mathrm{Ca}-\mathrm{Ca}$ distances of 3.443(4) A.

The bonding preferences of metal cations depend e.g. on the Lewis acidity and the softness. The hard $\mathrm{Fe}^{3+}$ ion tends to bond to only oxygen in oxohalides ${ }^{7,12,13}$ while the weaker Lewis acids $\mathrm{Cu}^{2+}$ and $\mathrm{Ni}^{2+}$ tend to bond to both oxygen and halide ions and $\mathrm{Cu}^{+}$tends to bond only to halide ions. ${ }^{5,6,14}$ There are also two crystallographically different $\mathrm{Fe}^{3+}$ positions in $1 . \mathrm{Fe}(1)$ is bonded to six $\mathrm{O}$ atoms at distances in the range

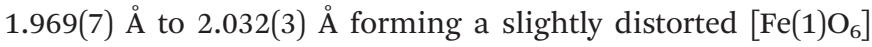
octahedron. However, $\mathrm{Fe}(2)$ is surrounded by four $\mathrm{O}$ atoms and two crystallographically different $\mathrm{Cl}$ atoms to form a highly distorted $\left[\mathrm{Fe}(2) \mathrm{O}_{4} \mathrm{Cl}_{2}\right]$ octahedron with $\mathrm{Fe}-\mathrm{Cl}$ distances of 2.332(3) $\AA$ for $\mathrm{Cl}(2)$ and 2.896(2) $\AA$ for $\mathrm{Cl}(1)$. The BVS values of $\mathrm{Cl}(1)$ and $\mathrm{Cl}(2)$ are only 0.34 and 0.52 respectively, indicating that they rather take the role of counter ions than being fully integrated in the covalent/ionic network; it is common that $\mathrm{Cl}^{-}$ions show low BVS values in oxochlorides and thus form only weak bonds to cations. ${ }^{18,19}$

The $\left[\mathrm{Fe}(1) \mathrm{O}_{6}\right]$ and $\left[\mathrm{Fe}(2) \mathrm{O}_{4} \mathrm{Cl}_{2}\right]$ polyhedra are connected via corner sharing to form wave-like chains with the simplified formula $\left[\mathrm{FeO}_{4} \mathrm{Cl}\right]_{\infty}$ running along [001]. Three such chains are connected to each other via a common $\mathrm{Cl}(1)$ atom to form a three-fold column having the formula $\left[\mathrm{Fe}_{6} \mathrm{O}_{24} \mathrm{Cl}_{4}\right]_{\infty}$ where the $\left[\mathrm{Ca}_{2} \mathrm{O}_{9}\right]$ dimers are located and bond via corner sharing to $\left[\mathrm{Fe}(1) \mathrm{O}_{6}\right]$ octahedra to form $\left[\mathrm{Fe}_{6} \mathrm{Ca}_{2} \mathrm{O}_{27} \mathrm{Cl}_{4}\right]_{\infty}$ building units that make up the 3D framework, see Fig. 2. The $\left[\mathrm{SeO}_{3} \mathrm{E}\right]$ tetrahedra are connected to those building units via corner sharing so that the lone-pairs on $\mathrm{Se}^{4+}$ and $\mathrm{Cl}(2)$ coordinated to $\mathrm{Fe}(2)$ protrude into the channels.

In the center of the channels there is a weak electron density observed from the Fourier map that emanates from water molecules introduced during synthesis, see the inset in Fig. 1. This was confirmed by powder X-ray diffraction (PXRD) carried out first on as-prepared powder and later on the same powder dried under vacuum. An intensity enhancement was observed for the 100 and the 110 peaks respectively after drying the powder. This is also observed in calculated PXRD patterns from the single crystal data when the residual electron density in the channels is included and excluded respectively, see ESI. $\dagger$

There is a continuous weight loss that adds up to $6 \mathrm{wt} \%$ when heating 1 from room temperature to $400{ }^{\circ} \mathrm{C}$ that seems to be attributed to loss of water located in the channels of the crystal structure (Fig. 3). The high temperature needed before all water has left the sample means that the water molecules are quite strongly attracted. Decomposition of the material takes place in two main steps. In the first step a weight loss of $\sim 46 \mathrm{wt} \%$ in the range $410-560{ }^{\circ} \mathrm{C}$ corresponds to the loss of seven molecules of $\mathrm{SeO}_{2}$ from the formula $\mathrm{Fe}_{6} \mathrm{Ca}_{2}\left(\mathrm{SeO}_{3}\right)_{9} \mathrm{Cl}_{4}$. EDS analysis of powder from a decomposition experiment interrupted at $700{ }^{\circ} \mathrm{C}$ confirms that both $\mathrm{Cl}$ and also some Se are left in the solid material. A second decomposition step takes place in the temperature range $790-890{ }^{\circ} \mathrm{C}$ where the

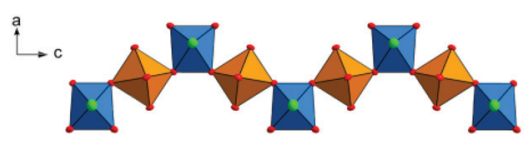

(a)

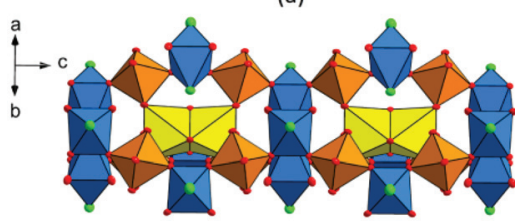

(C)

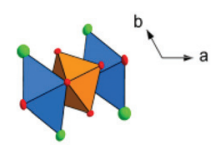

(b)

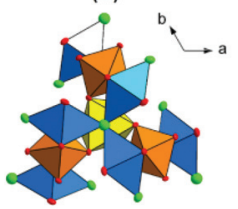

(d)
Fig. 2 (a-b) $\left[\mathrm{FeO}_{4} \mathrm{Cl}\right]_{\infty}$ chain built by corner sharing of $\left[\mathrm{Fe}(1) \mathrm{O}_{6}\right]$ and $[\mathrm{Fe}(2)$ $\mathrm{O}_{4} \mathrm{Cl}_{2}$ ] octahedra viewed along [010]. (c-d) Three single chains are connected via a common $\mathrm{Cl}(1)$ to form columns having the formula $\left[\mathrm{Fe}_{6} \mathrm{O}_{24} \mathrm{Cl}_{4}\right]_{\infty}$. Those columns host the $\left[\mathrm{Ca}_{2} \mathrm{O}_{9}\right]$ dimers to form the complex building unit $\left[\mathrm{Fe}_{6} \mathrm{Ca}_{2} \mathrm{O}_{27} \mathrm{Cl}_{4}\right]_{\infty}$ that connects to make up the framework structure. 


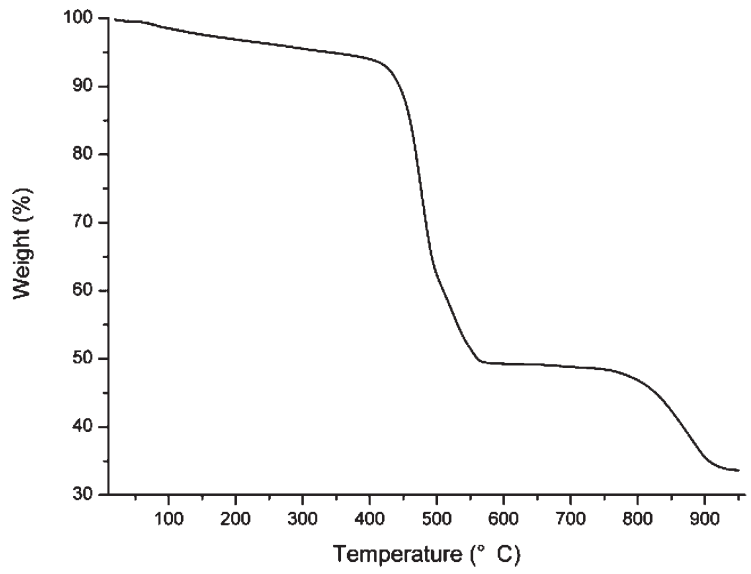

Fig. 3 TG curve of $\mathrm{Fe}_{6} \mathrm{Ca}_{2}\left(\mathrm{SeO}_{3}\right)_{9} \mathrm{Cl}_{4}$ for the range $20^{\circ} \mathrm{C}$ to $950{ }^{\circ} \mathrm{C}$, see text for explanation.

remaining Se and $\mathrm{Cl}$ leave the sample as confirmed by EDS, see ESI. $\uparrow$ The total weight loss during the decomposition from 400 to $950{ }^{\circ} \mathrm{C}$ is $63 \mathrm{wt} \%$, which is close to the expected weight loss $\left(67 \mathrm{wt} \%\right.$ ) corresponding to nine formula units of $\mathrm{SeO}_{2}$ plus two formula units of $\mathrm{Cl}_{2}$ leaving the starting compound. It was possible to identify the presence of $\alpha-\mathrm{Fe}_{2} \mathrm{O}_{3}$ from powder X-ray diffraction and in addition there is at least one unidentified phase that contains both Fe and Ca.

Gas sorption experiments were performed to confirm if the pores in $\mathbf{1}$ are accessible for gas uptake. Water vapour sorption measurements yield a slight uptake around a relative pressure of $P / P_{0} \sim 0.1$ followed by saturation until $\sim 0.85$. At a relative pressure of $\sim 0.89$ an instant and significant uptake followed by saturation was observed, see Fig. 4 . The saturation at high pressure eliminates the possibility that it is water condensation on the particle surfaces that takes place as it then should be a continuous uptake without saturation when $P / P_{0}$ approaches $1 .^{20}$ It was confirmed by PXRD that there was no

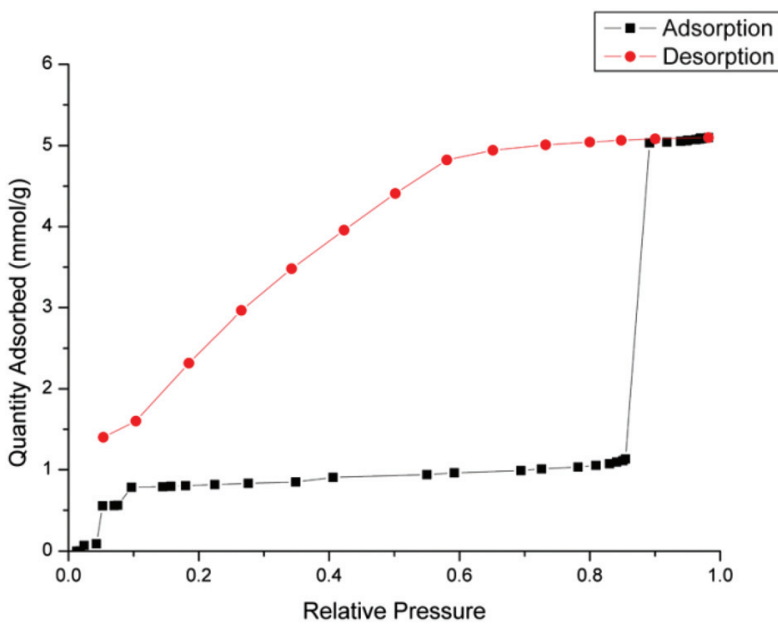

Fig. 4 Water vapour sorption isotherm on $\mathrm{Fe}_{6} \mathrm{Ca}_{2}\left(\mathrm{SeO}_{3}\right)_{9} \mathrm{Cl}_{4}$ at $293 \mathrm{~K}$, see text for explanation. phase transition of $\mathbf{1}$ associated with the water uptake, just the intensity changes due to water uptake discussed above.

The adsorbed amount of water saturated at $5 \mathrm{mmol} \mathrm{g}^{-1}$ corresponds to a weight gain of $9 \mathrm{wt} \%$. With decreasing water vapour pressure, the adsorbed water slowly desorbed forming an apparent hysteresis loop. There was still a water uptake of about $1.4 \mathrm{mmol} \mathrm{g}^{-1}$ left at the end of the desorption process, meaning that water molecules are confined to the channels, which is also in good agreement with the TG experiment where a slow weight loss takes place when heating from 100 to $400{ }^{\circ} \mathrm{C}$. The $\mathrm{CO}_{2}$ isotherm also shows an apparent hysteresis loop and yields a Langmuir surface area of $25.3 \mathrm{~m}^{2} \mathrm{~g}^{-1}$, see ESI. $\dagger$ The sorption hysteresis exhibited in the above two measurements suggests constricted pores in the framework. Only a very small surface area was observed when performing adsorption experiments with $\mathrm{N}_{2}$. Similar results of $\mathrm{CO}_{2}$ and $\mathrm{N}_{2}$ sorption are obtained also for the porous framework compound $\left[\mathrm{M}_{2}\left(\mathrm{UO}_{2}\right)_{6}\left(\mathrm{PO}_{3} \mathrm{CH}_{2} \mathrm{CO}_{2}\right)_{3} \mathrm{O}_{3}(\mathrm{OH})\left(\mathrm{H}_{2} \mathrm{O}\right)_{2}\right] \cdot 16 \mathrm{H}_{2} \mathrm{O} \quad(\mathrm{M}=$ $\mathrm{Mn}, \mathrm{Co}, \mathrm{Cd}){ }^{21}$

In summary, compound $\mathbf{1}$ has been obtained by solid state reactions. The crystal structure can be described as an open 3D-framework containing unusually large channels having a diameter of $\sim 6.4 \AA$. The framework structure is built by corner sharing $\left[\mathrm{Fe}(1) \mathrm{O}_{6}\right]$ and $\left[\mathrm{Fe}(2) \mathrm{O}_{4} \mathrm{Cl}_{2}\right]$ polyhedra. The $\left[\mathrm{Ca}_{2} \mathrm{O}_{9}\right]$ and $\left[\mathrm{SeO}_{3}\right]$ groups are connected to the framework. The accessibility of channels to guest molecules has been confirmed by gas sorption measurements and PXRD. The title compound gained a weight of $9 \mathrm{wt} \%$ during water vapor sorption experiments and the $\mathrm{CO}_{2}$ isotherm shows a Langmuir surface area of $25.3 \mathrm{~m}^{2} \mathrm{~g}^{-1}$.

\section{Notes and references}

$\ddagger$ Further details on the crystal structural investigation of $\mathbf{1}$ can be obtained from the Fachinformationszentrum Karlsruhe, Abt. PROKA, 76344 Eggenstein-Leopoldshafen, Germany (fax +49-7247-808-666; E-mail: crysdata@fiz-karlsruhe.de) on quoting the depository number CSD 425846.

1 J. Galy, G. Meunier, S. Andersson and A. Astrom, J. Solid State Chem., 1975, 13, 142.

2 R. Seshadri and N. A. Hill, Chem. Mater., 2001, 13, 2892.

3 K. M. Ok and P. S. Halasyamani, Angew. Chem., Int. Ed., 2004, 43, 5489.

4 R. Becker, M. Johnsson, R. Kremer and P. Lemmens, J. Solid State Chem., 2005, 178, 2024.

5 Z. Mayerová, M. Johnsson and S. Lidin, Angew. Chem., Int. $E d ., 2006,45,5602$.

6 M. Johnsson, K. W. Törnroos, F. Mila and P. Millet, Chem. Mater., 2000, 12, 2853.

7 R. Becker, M. Johnsson, R. K. Kremer, H.-H. Klauss and P. Lemmens, J. Am. Chem. Soc., 2006, 128, 15469.

8 S.-H. Kim, J. Yeon and P. S. Halasyamani, Chem. Mater., 2009, 21, 5335.

9 S. D. Nguyen and P. S. Halasyamani, Inorg. Chem., 2012, 51, 9529. 
10 C.-F. Sun, C.-L. Hu, X. Xu, B.-P. Yang and J.-G. Mao, J. Am. Chem. Soc., 2011, 133, 5561.

11 R. Becker, H. Berger, M. Johnsson, M. Prester, Z. Marohnic, M. Miljak and M. Herak, J. Solid State Chem., 2006, 179, 836.

12 D. Zhang, R. K. Kremer, P. Lemmens, K.-Y. Choi, J. Liu, M.-H. Whangbo, H. Berger, Y. Skourski and M. Johnsson, Inorg. Chem., 2011, 50, 12877.

13 D. Zhang, M. Johnsson, H. Berger, R. K. Kremer, D. Wulferding and P. Lemmens, Inorg. Chem., 2009, 48, 6599.

14 H.-L. Jiang and J.-G. Mao, Inorg. Chem., 2006, 45, 7593.

15 D. Zhang, M. Johnsson, S. Lidin and R. K. Kremer, Dalton Trans., 2013, 42, 1394.

16 Needle like crystals of 1 were obtained by starting with $0.160 \mathrm{~g} \mathrm{Fe}_{2} \mathrm{O}_{3}$ (ABCR, 99\%), $0.111 \mathrm{~g} \mathrm{SeO}_{2}$ (Alfa Aesar 99\%) and $0.056 \mathrm{~g} \mathrm{CaO}$ (ABCR, 99\%). Single crystals were obtained after heating at $200{ }^{\circ} \mathrm{C}$ for four days in sealed evacuated silica tubes containing also $80 \mu \mathrm{L}$ concentrated $\mathrm{HCl}(37 \%)$. The tubes were placed in a steel autoclave with water during the heat treatment in order to generate a counter pressure.

17 J.-G. Mao, H.-L. Jiang and F. Kong, Inorg. Chem., 2008, 47, 8498.

18 R. Becker, M. Johnsson and H. Berger, Z. Anorg. Allg. Chem., 2007, 633, 422.

19 R. Becker, M. Prester, H. Berger, M. Johnsson, D. Drobac and I. Zivkovic, Solid State Sci., 2007, 9, 223.

20 J. Ferrando-Soria, R. Ruiz-García, J. Cano, S.-E. Stiriba, J. Vallejo, I. Castro, M. Julve, F. Lloret, P. Amorós, J. Pasán, C. Ruiz-Pérez, Y. Journaux and E. Pardo, Chem.-Eur. J., 2012, 18, 1608.

21 A. N. Alsobrook, B. G. Hauser, J. T. Hupp, E. V. Alekseev, W. Depmeier and T. E. Albrecht-Schmitt, Chem. Commun., 2010, 46, 9167. 